\title{
HISTORY OF THE FIRST PRESBYTERIAN CHURCH
} OF MUSCATINE, IOWA.

EXTRACTED FROM A THANKSGIVING SERKON PREACHED TOTEMBER 24, 1859, BY ITS THEN PASTOR, REV. E. L. BELDEN. ${ }^{\prime}$

The first Church ever organized in this county, (Muscatine) was the Methodist ${ }^{\gamma}$ Episeopal, which was organized in May 1839. July 6th of the same year the Rev. John Stocker, originally a Congregational minister in Vermont, but who, on his removal to Indiana, several years previous, had united with the Presbyterian Church, and whose name is found on the minutes of our General Assembly for 1837, 1839, 1841, and so on until his death in 1846, organized at the house of Stephen Whicher, a church consisting of the following persons: H. Q. Jennison and wife, Samuel Lucas and wife, Stephen Whicher and wife, Erastus 'Scofield and Mrs. Elizabeth Stocker, with Harvey Gillett, who was admitted on profession of his faith the same day; making in all nine, none of whom are now members of this Church. S. Whicher and Samuel Lucas were elected ruling elders. The name given to the organiza. tion was, "The First Presbyterian Church of Muscatine County, Iowa Territory."

It was resolved at the first meeting "that we cordially receive the Presbyterian Confession of Faith ;" also, "that in the formation of this Church, remote as we are from sourees of infornation in regard to what has been done, or is doing, in the General Assembly of the Presbyterian Church of the United States on the subject of a division of that Assembly, we do not intend in the event of a division to connect ourselves with that part which united in excinding the Synod of Geneva, and others in 1837." The Church, therefore, remained unconnected with either the Old or New School Presbyteries for some three years, during which time $\mathrm{Mr}$. Stocker ministered to it, the congregation worshipping sometimes in the Methodist Church, which stood on Iowa avenue, nearly opposite the Nerada Mill, in a room on Water street, above the Ogilvie House; sometimes in the upper room of a building on Second 
street, where Wilson's grocery now. is; and sometimes in a log house on the corner, where $\mathrm{Mr}$. Brewster's dwelling-house now stands. April 10th, 1840, Mr. Azel Farnsworth and wife were received from the Presbyterian Church of Alden, New York, Mrs. Ogilvie, from the Presbyterian Church of Keith, Scotland, and three other persons from Congregational Churches in the East. From this time until January, 1842, there were added to the communion by letter from Presbyterian Churches, 3 ; from Congregational 2 ; and on examination, 7 ; and one was dismissed, so that in the beginning of 1842 there were 26 members. About the 1st and $2 \mathrm{~d}$ of June 1842, some proceedings seem to have been had, concerning which the records are profoundly silent, and in regard to which, those who were present disagree. It is admitted that, Mr. Stocker, insisting that the Church should connect itself with either the Old or New School Presbytery, a meeting was held to decide which they would join. At this meeting, it is claimed by those favoring the New School, that the vote stood 14 to 11 , giving them a majority of 3 . Of this their record says nothing, thongh they give the procecdings of a meeting of session January 1st, 1842, of which Rev. Wm. C. 'Rankin, a New School minister, was moderator. Also, of a church meeting the next day, at which H. Q. Jennison and Pliny Fay were elected elders, the two existing elders having also gone with the New School, and Isaac Magoon and $O$. M. Lovett were elected deacons. At this meeting there were present, besides Mr. Rankin, Mr. and Mrs. Stocker, twelve persons, all belonging to the New School. They engaged Dr. Wood, of Iowa City, to preach to them half his time, worshipping for some months in the Court House.

They united with the New School Presbytery, sent a delegate to its meeting at Yellow Springs, when their records were approved by Presbytery for the first and last time, Sept. 9th, 1842. Sept. 24th, 1842, they had their last regular meeting of session. Sometime in 1843, the Congregational Church was organized, and all the members of the New School Church joined it except Mr. Whicher. The New School Church had a nominal existence in him until the summer of 6 
1845 , when the organization was formally dissolved hy Presbytery, and sometime after he entered the Congregational Chureh.

To return to the Old School.-In our Session Book are the recoids of a meeting held by the Old School members, Feb. $2 \mathrm{~d}, 1842$, according to previous notice from the pulpit; in which notice it was stated that at the previous meeting to deeide between the Old and New School, there was an equal number of votes on each side, the chairman not voting, but known to be on the Old School side; that therefore, and for the additional reason that "the undersigned being satisfied that the New School branch of the church claiming to be Presbyterian, has departed from the standards of the General Assembly of the Presbyterian Church in the United States, both in government and doctrine," the succession rightfully belonged to the Old School. At the meeting held at this time, it was roted that this church be called the first Presbyterian Church of Bloomington, and be connected with the Presbytery of Iowa, which was done, and this church appears on the minutes of our General Assembly in $\mathbf{1 8 4 3}$ for the first time. At this meeting Azel Farnsworth was elected ruling elder, and subsequently accepting the office, he was ordained and installed March 19th, 1842, after sermon by Rev. Mr. Hummer. The next day, the Sacrament of the Lord's Supper, was administered. Of the twelve persons who were members at that time, only two are now in communion with this church. Mr. Farnsworth* and Mrs. Ogilvie. Five are known to be deceased, and five have removed from the place. Jan. 25th, 1845, a legal organization of the church, enabling it to hold property, etc., was effected agreeably to an act of the Territorial Legislature, passed Feb. 7th, 1844. Joseph "Bennett, T. M. Isett and R. P. Lowe, were elected the first trustees.

The congregation met for worship first in the old Episcopal Church, then in a building where Stines' block now stands, and then in the basement of the Baptist Chúrch. Feb. 14th, 1846, the congregation resolved to make an effort to build a house of worship to cost about $\$ 2,000$, and appointed J. Ben-

*Who has since left and united with the Methodist Episcopal Church. 
nett, A. Ogilvie, R. P. Lowe and Geo. W. Fitch, building committee. This effort however, did not succeed, and the first building owned by this church was the one still standing on Mulberry street, which was built in 1849 , at a cost of about $\$ 4,000$. That house was sold in 1855 , and the erection of the present edifice commenced in 1856 .

While it was building, the congregation met for more than a year in Hare's Hall. The first sermon was preached in this room by Rer. Dr. Curnmins, ${ }^{*}$ Dec. 1856 , and we first occupied the upper room in May 1858. This building has cost as near as I can get at it, about $\$ 22,000$. Our present indebtedness, 1859 , is in the neighborhood of $\$ 2,400$, with it is supposed, assets to the amount of $\$ 1,000$,-leaving some $\$ 1,500$ to be raised, which ought to be, and if all will do their part, can be paid off in the course of two years. Since 1842, nine persons have held the office of ruling elder in this church,- - six of whom still continue in office:-A. Farnsworth, ordained in 1842, left to join the Congregational Church in 1844 ,-was again received in our communion in 1858; Aulay McAulay was ordained. Nov. 1843 , resigned Jan. 20 th, $1850 ;$ J. H. Wallace, ordained in 1848 , resigned Jan. 15 th, 1853 ; T. S. Parvint and J. S. 'Horton were ordained Dec. 22d, 1850; Gabriel Little and Chs. 'O. Waters, April 6th, 1856 ; David Hoyt $\ddagger$ and Chas. 'Nealley, Jan. 30th, 1859. This church has never had any deacons, though three members were elected to that office a year ago. It has had eight ministers, three of whom have been pastors, and five have been stated supplies. Mr. Stočker's relation to the church ceased sometime in the spring of 1845 . He was succeeded in June of the same year by the Rev. F. A. Pratt, now of Lakeville, Minn., who remained here till the spring of 1847. Sometime in that year or early in 1848 , the Rev. John Hudson commenced his labors here, and preached as stated supply till early in 1849 , though during this period he was absent some months in the South collecting funds to aid in building a house of worship. Oct. 28 th, 1849 , Rev. Justus T. Um-

* Since deceased at an advanced age.

†Resigned and removed to Lowa City, 1860.

tSince decessed. 
sted, then a licentiate of the 1st Presbytery of Philadelphia, preached his first sermon in Muscatine. A call for his service was soon after made out, which he accepted and commenced his labors here, and was ordained and installed the first pastor of this church, Nov. 10th, 1850, at the first meeting of the Presbytery of Cedar. Mr. Umsted continued its pastor until Oet. 12th, 1852, when the pastoral relation was dissolved, and he soon after removed to Keokuk. The same fall Rev. Hugh 'Hutchinson, then a licentiate, was employed as stated supply, he remained here a little less than a year, removed to LeClaire, where he died in 1855. Rev. Saml. J.'Baird, now of Woodbury, N. J., commenced his labors here Dec. 25th, 1853, was installed pastor sometime the next yoar, and left in Nov. 1856. In Dec. 1856 , or in Jan. 1857, Rev. J. B. Stuart, now of Oxford, Ohio, was employed as stated supply, and supplied the pulpit till Feb. 1858, when he was succeeded by the present incumbent, who was ordained and installed May 5th of the same year. The whole number of memuers who have been connected with this church since its organization is $336 ; 217$ of these have been admitted by certiticate, and 119 on examination.

It may furnish some idea of the progress of the church to give the numbers admitted during certain periods. From 1842 to 1846 , ten persons were received on examination ; from Jan. 26 th, 1846 , to Jan. 19 th, 1850 ; - not a single person was received on profession of his faith. Four years without one addition from the world!!

From 1842 to 1850,63 persons were received by letter. During $\mathrm{Mr}$. Umsted's ministry, 29 were received on examination, 41 by letter; from Mr. Umsted's time till Mr. Baird's, 1 on examination, 10 by certificate ; during Mr. Baird's pastorate, 32 on examination, 67 by letter; during Mr. Stewart's ministry, 1 by letter; since he left, 47 on examination, 40 by certificate; or to sum up, in the space of 10 years under five ministers as stated supply, there were 11 accessions to the church on examination, and 74 by letter, while in the space of 7 years under three pastors, the accessions were 108 on examination, 
and 148 by letter. In 1845 this church reported to the General Assembly, 25 members; in 1847, 39 ; 53,60 ; in 1858, 110 ; and in 1859, 172. Of the 336 communicants, 124 have been dismissed to other churches; 22 have been suspended or stricken from the roll; 3 have been excommunicated, and 26 have died while in connection with this church. The present membership numbers 161 ; of these 134 are living in this city, or the vicinity, 27 being either temporarily absent or having removed without yet taking their letters of dismissal. Three members of this church have been licensed to preach the gospel,-Jno. L. Cummins, Joseph Iddings and C. O. Waters.

When we look on the field already white for the harvest, and see how many more laborers are needed, let us pray the Lord of the harvest, that $\mathrm{He}$ will raise up, qualify and send forth from among us many more, who shall be efficient in gathering in His sheaves.

From 1842 to 1851, this church received aid from our Board of Domestic Missions, without which most of the time, it would have been unable to support a pastor. The total amount received from that source, must have been some $\$ 2,000$, as $\$ 300$ was supplied by the Board in one year. Now that we have become self-sustaining and able to help others, let us, remembering our obligations to this Board, contribute liberally to its treasury, that it may be able to plant and nurture other churches, from which shall flow out streams of blessing to gladden the world.

In 1834 , the first settlement was made in this county. In 1839, the first brick house was erected in Muscatine. In February of this year, the population was 71 , with only four or five children. Now the estimated population of the city is 7,000, with more than 1,000 Sabbath School scholars.

The church has also made progress, not only in this city and State, but throughout the entire North-West, as well as in the whole country. At the first meeting of the Presbytery of Schuyler in 1832, that Presbytery embracing the whole of Wiscousin, Minnesota, Iowa, and about half of Illinois, consisted of five ministers and three churches. Now within the same limits we have 15 Presbyteries, 220 ministers, and 318 
churches, leaving out of view the New School. When this church was organized, there were but two Old School churches in the Territory of Iowa. In 1842 the Presbytery with which this church connected itself embraced the whole Territory, and contained 7 ministers, 13 churches, and 323 members. Now there are in this State 2 Synods, 6 P'resbyteries, 80 ministers, 128 churches, and 5,300 members. The number of Old School Presbyterians in this State exceeds that of the Congregationalist's some 500 ; of the New School some 3,000 , and is I believe exceeded by no demomination except the Methódist.

\section{HISTORICAL SOCIETY.}

During the summer the Board of Curators have not regularly met.

The donations to the Library and Cabinet have, however, been constant and extensive.

The Board of Curators unanimously resolved to continne the publication of the AnNaLs, the subscriptions to which have doubled within the last three months.

They also resolved to have the files of newspapers of the State bound for more convenient reference. These papers are particularly valuable for the many matters they contain elucidating the war history of our patriotic State.

Among the many contributors we may mention, in the way of books and pamphlets, the several Departments at Washington, Dr. Wright, Secretary of State at Des Moines, Hon. J. A. Raum, Secretary of Dakotah Territory, Profs. Parvin and Wells, Col. Henderson and Capt. Williams, of the 44th.

The following persons have contributed largely in the way of battle flags, war relics, and specimens for the cabinet of 
Copyright of Annals of Iowa is the property of State of Iowa, by \& through the State Historical Society of Iowa and its content may not be copied or emailed to multiple sites or posted to a listserv without the copyright holder's express written permission. However, users may print, download, or email articles for individual use. 